\title{
Miocene to Pliocene Paleoceanography of the Western Equatorial Pacific Ocean Based on Calcareous Nannofossils, ODP Hole 805B
}

\author{
Meutia Farida, Ryo Imai, Tokiyuki Sato \\ Institute of Applied Earth Sciences, Faculty of Engineering and Resource Science, \\ Akita University, Akita, Japan \\ Email:meutia_farida03@yahoo.com,\{imai,toki\}@keigo.mine.akita-u.ac.jp
}

Received February 7, 2012; revised March 8, 2012; accepted April 2, 2012

\begin{abstract}
We describe in detail the Miocene to Quaternary paleoceanography of the western equatorial Pacific Ocean based on calcareous nannofossils of Hole 805B. The relative abundance of Discoaster which lived in the lower photic zone under the stable sea with nutricline and thermocline, decreased step by step at NN5/NN6 and NN10/NN11 boundaries. Although the size of Reticulofenestra which is strongly influenced by nutrient, increased five times throughout the section, it drastically decreased in NN4-5 zone, NN10, NN12, and in NN15/NN16 boundary. On the basis of the relationship between Discoaster abundance and Reticulofenestra size change, collapse of the stability of the sea surface in the western equatorial Pacific Ocean progressed step by step throughout the Miocene to Quaternary.
\end{abstract}

Keywords: Paleoceanography; Calcareous Nannofossils; Discoaster; Reticulofenestra; Nutricline; Thermocline

\section{Introduction}

Calcareous nannofossils, which have been widely distributed in the world's oceans since the Mesozoic, are well known as a useful tool for paleoenvironmental analysis as well as for age determination. A living nannofossil species, Florisphaera profunda, which is presently found in lower photic zone [1], is a proxy to reconstruct the stability of the Quaternary sea surface condition with nutricline and thermocline. However, as F. profunda is not found in the Pliocene or older sections, it was difficult to reconstruct the sea surface conditions during the Neogene Period.

Recently, it became gradually clear that the size changes of coccolith and productivity of nannoplankton are strongly influenced by sea surface conditions such as the presence of nutricline, thermocline or upwellings $[2$, 3]. Furthermore, as Discoaster which last appeared in 2.0 Ma [4], is indicated as a lower photic zone species same as F. profunda, abundant occurrence of Discoaster indicates the sea surface stratification and the oligotrophic condition. On the basis of these phenomena, firstly we describe in detail the calcareous nannofossil assemblages of Ocean Drilling Program (ODP), Hole 805B located in the western equatorial Pacific Ocean, and then we discuss the sea surface stability of the ocean from the Miocene to the Pleistocene, focusing on both the cocco- lith size and Discoaster abundance changes.

\section{Oceanographic Setting}

Hole $805 \mathrm{~B}$ is situated in $3188 \mathrm{~m}$ of water on the northwestern margin of the Ontong Java Plateau, close to the equator of the western equatorial Pacific Ocean, (latitude $1^{\circ} 13.68^{\prime} \mathrm{N}$, longitude $160^{\circ} 31.76^{\prime} \mathrm{E}$ ).

This site is influenced under variable world ocean circulation systems (Figure 1), such as, North Equatorial Current (NEC), North Equatorial Countercurrent (NECC), and Indonesian Throughflow (IT), in association with the New Guinea Coastal Undercurrent (NGCUC), the South Equatorial Current (SEC), and Equatorial Undercurrent (EUC), respectively. The western equatorial Pacific Ocean is dominated by the Western Pacific Water Pool (WPWP), which is characterized by a thick mixed layer, a deep, well-developed thermocline, and a deep maximum chlorophyll [5].

\section{Samples and Methods}

The sedimentary section at Site 805 is stratigraphically complete, covering the Pleistocene to the upper Oligocene. The sedimentary sequence was devided into two subunits (IA and IB) based on the degree of consolidation. The subunit IA from $805 \mathrm{~B}-1 \mathrm{H}$ to $805 \mathrm{~B}-30 \mathrm{X}$ is composed of nannofossil ooze to foraminifer nannofossil 


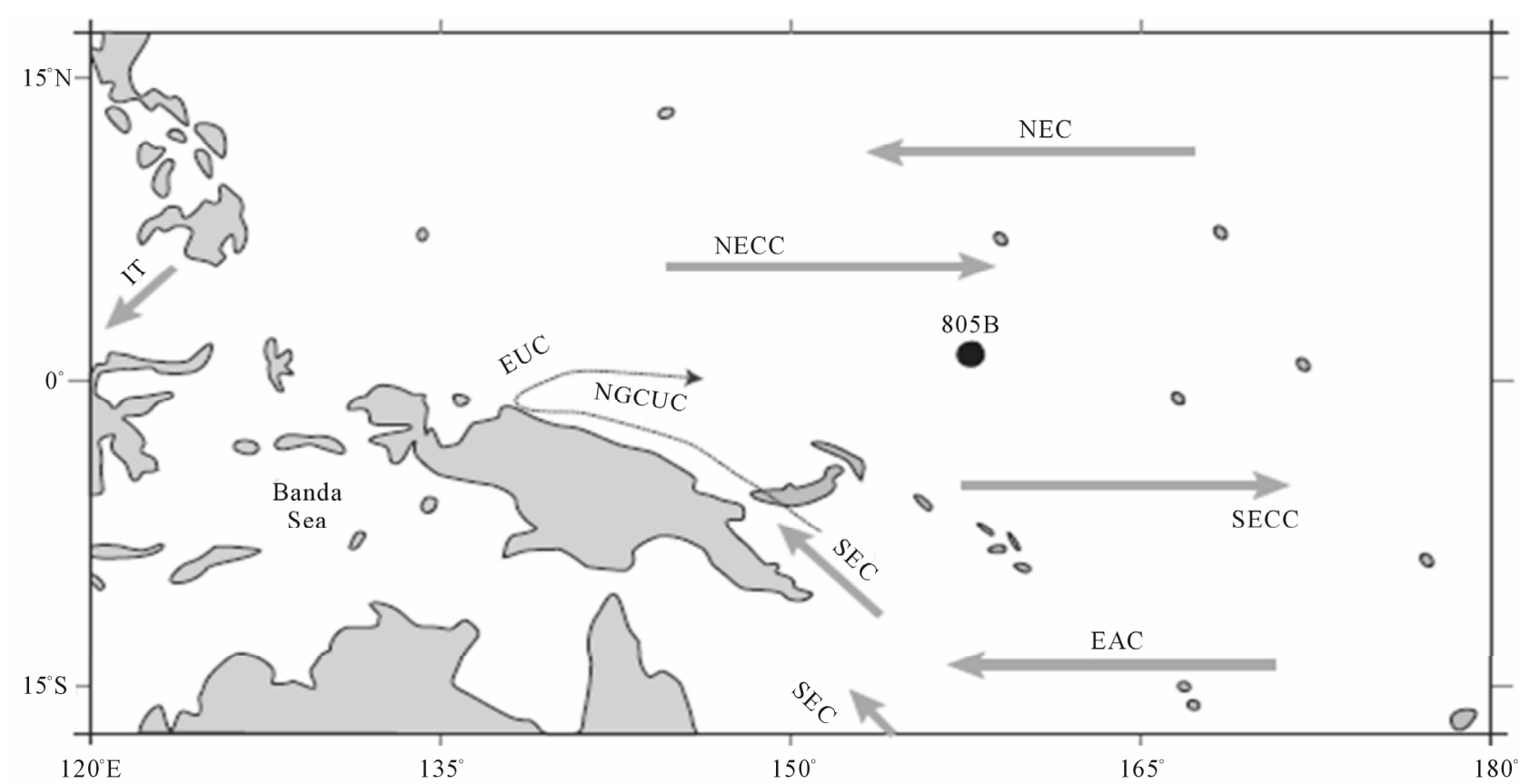

Figure 1. Location of Hole 805B and the major current systems of SE Asia. NEC (North Equatorial Current), NECC (North Equatorial Countercurrent), SEC (South Equatorial Current), SECC (South Equatorial Countercurrent), EAC (East Australian Current), IT (Indonesian Throughflow), EUC (Equatorial Undercurrent), NGCUC (New Guinea Coastal Undercurrent).

ooze, and subunit IB $805 \mathrm{~B}-31 \mathrm{X}$ to $50 \mathrm{X}$ is characterized by nannofossil chalk to foraminifer nannofossil chalk [6]. We examined Hole $805 \mathrm{~B}$ of this site.

A total of 317 samples from ODP Hole 805B were made samples preparation. The sample of $0.0400 \mathrm{~g}$ (after pounded to be powder) was placed in a breaker, and then $50 \mathrm{ml}$ of water was added. After suspension, $0.5 \mathrm{ml}$ of suspension was pippetting to be evenly distributed on a cover glass $(18 \mathrm{~mm} \times 18 \mathrm{~mm})$. The cover glass was carefully dried on an electric hot plate set at $40^{\circ} \mathrm{C}$, and placed on a slide glass with embedded medium to make slides. The slide was examined under a binocular polarizing microscope with an oil-immersion objective at lens at $1.500 \times$ magnification.

Several thousands coccolith and Discoaster were observed to recognized both their last and first occurrence horizons. After that, to obtain their floral change through the examined geological time, 200 specimens were counted at random. In addition, number of coccolith and Discoaster were counted in the area of one survey line $(18 \mathrm{~mm} \times 10 \mu \mathrm{m})$ to be estimated the quantitative amount of accumulation in a unit of sample weight (the number/gram). The size distribution of Reticulofenestra spp. was also measured to the 50 to 100 Reticulofenestra specimens in each sample.

\section{Biostratigraphy}

The zonal scheme by Martini [7], is applied for in this study. Calcareous nannofossil flora are characterized by abundant occurrence of Reticulofenestra spp. throughout the section (Figure 2). Coccolithus pelagicus, which is commonly distributed in the high latitude regions near Greenland [8,9], occurs abundantly below $220 \mathrm{~m}$. Calcidiscus leptoporus are found commonly in the middle to upper section of Hole 805B, whereas the samples in the lower part are characterized by the Miocene marker species such as Cyclicargolithus floridanus, Sphenolithus moriformis and Sphenolithus heteromorphus.

The last occurence of Pseudoemiliania lacunosa, defined the Zone NN20/NN19 boundary, was observed in samples between 130-805B-1H-CC (6.7 mbsf) and 130805B-2H-CC (16.2 mbsf).

The zonal boundary of NN19/NN18 was defined by the last occurence of Discoaster brouweri, was identified in samples between 3H-CC (25.7 mbsf) and 4H-CC (35.2 mbsf). The last occurrences of Discoaster pentaradiatus and Discoaster surculus which mark the NN17/NN18 and NN17/NN16 boundaries respectively, are found between samples $4 \mathrm{H}-\mathrm{CC}(35.2 \mathrm{mbsf}) / 5 \mathrm{H}-\mathrm{CC}(44.7 \mathrm{mbsf})$, and $6 \mathrm{H}-\mathrm{CC}(54.2 \mathrm{mbsf}) / 8 \mathrm{H}-223-24 \mathrm{~cm}(65.43 \mathrm{mbsf})$, respectively. The NN15/NN16 boundary which is defined by the last occurrence of Reticulofenestra pseudoumbilicus is traceable in the horizon between samples 8H-CC (73.2 mbsf)/9H-1, 23 - 24cm (73.43 mbsf). Ceratolithus rugosus which defines NN12/NN13 boundary is found between samples $11 \mathrm{H}-3,23-24 \mathrm{~cm}(95.43 \mathrm{mbsf})$ and $11 \mathrm{H}-5,23-24 \mathrm{~cm}(98.43 \mathrm{mbsf})$. Both the last occur- 


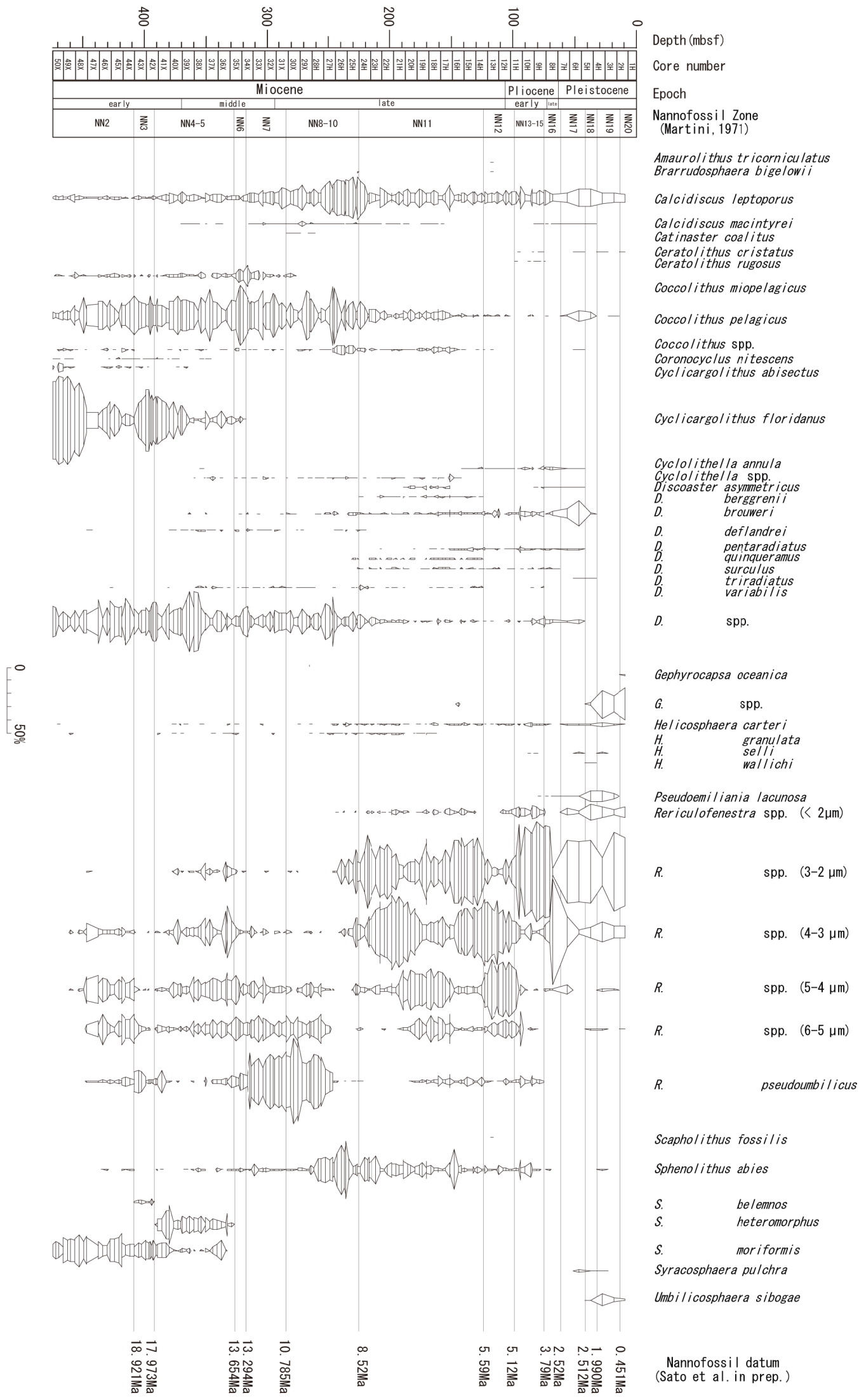

Figure 2. Distribution of nannofossils in Hole 805B. 
rence of Discoaster quinqueramus and the first occurrence of $D$. berggrenii which indicate top and bottom of NN11 zone are found in samples between 14H-1, 23 - 24 cm (120.93 mbsf)/14H-3, 23 - $24 \mathrm{~cm}$ (123.93 mbsf) and between $24 \mathrm{H}-5,23$ - $24 \mathrm{~cm}$ (221.93 mbsf)/24H-7, 23 - 24 cm (224.93 mbsf).

Although the first occurrence of Catinaster coalitus, which marks the NN7/NN8 boundary, is situated between 30X-CC (282.5 mbsf)/31X-1, 23 - $24 \mathrm{~m}$ (282.73 mbsf), Discoaster hamatus which defines both top and bottom of NN9 zone is not found throughout the section. Based on the last occurrences of Cyclicargolithus floridanus and Sphenolithus heteromorphus, the NN6/NN7 and NN5/NN6 boundaries are traceable to between $34 \mathrm{X}-3,23$ - $24 \mathrm{~cm}$ (314.23mbsf)/34X-5, $23-24 \mathrm{~cm}$ (317.23 mbsf) and between 35X-3, $23-24 \mathrm{~cm}(323.73$ mbsf)/35X-5, 23 - $24 \mathrm{~cm}$ (326.73 mbsf). As Helicoshaera ampliaperta which defines the top of NN4 zone, is not found in the section, NN4/NN5 boundary is not detected. The first and last occurrences of Sphenolithus belemnos which mark NN3 Zone, are traceable to between 42X-2,
25 - $26 \mathrm{~cm}$ (389.75 mbsf)/42X-3, 23 - $24 \mathrm{~cm}(391.23$ mbsf) and between 43X-CC (407.30 mbsf)/44X-1, 23 $24 \mathrm{~cm}$ (407.53 mbsf). Discoaster druggi the marker species of NN1 Zone is not found throughout the section.

On the basis of distributions of marker species mentioned above, the sequence in this study is correlated to NN2 to NN20 Zone from the early Miocene to Pleistocene.

\section{Productivity and Size Variation}

Coccolith and Discoaster are phytoplankton that the amount of these microfossils are roughly reflected to the primary productivity. The size variation of Reticulofenestra through time is also well known worlwide, but there are a few quantitative data.

\subsection{Coccolith and Discoaster Productivity}

We examined the coccolith and Discoaster productivity as shown in Figure 3.

From NN2 Zone to the upper part of NN4-5 Zone, the
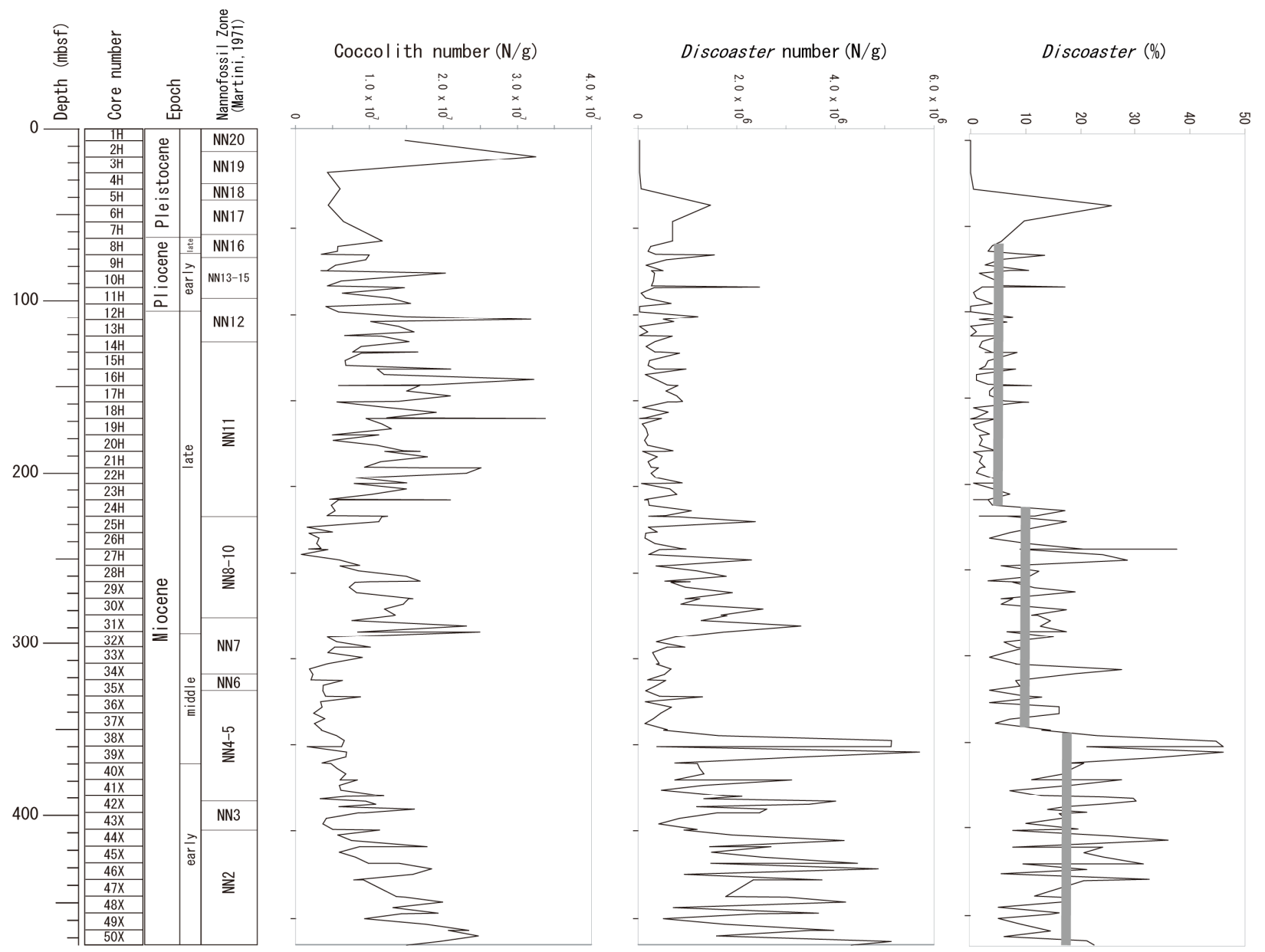

Figure 3. Comparison between Coccolith and Discoaster number (N/g), and relative abundance of Discoaster (\%). Grey solid line indicates the mean of Discoaster percentage. 
number of coccolith productivity decreased around $3.0 \times$ $10^{7} \mathrm{~N} / \mathrm{g}$ through less then $1.0 \times 10^{7} \mathrm{~N} / \mathrm{g}$. Otherwise Discoaster productivity was recognized at a maximum in this period, reaching approximately $6.0 \times 10^{6} \mathrm{~N} / \mathrm{g}$ $(\sim 50 \%)$. From the upper part of NN4-5 Zone through the upper part of NN8-10 Zone, the coccolith is likely to increase in number. On the other hand, Discoaster in the sequence of the upper part of NN4-5 to NN7 Zones decreased abruptly. The section above the NN7/NN8 boundary is marked by increasing Discoaster again until approximately $4.0 \times 10^{6} \mathrm{~N} / \mathrm{g}$, and then its number gradually decreased towards the upper Pliocene.

From the upper part of NN8-10 to NN16, the amount of coccolith increased in NN11, indicating the highest peak around $3.5 \times 10^{7} \mathrm{~N} / \mathrm{g}$. The relative abundance of Discoasters is also shown in Figure $\mathbf{3}$ as an indicator the surface water stability. The relative abundance of Discoaster specimens steps down throughout the sequence. Although the average of the relative abundance is scored at about $15 \%$ in the interval from NN2 to the upper part of NN4-5 Zone, the average decreased step-wise from $10 \%$ in the upper part of NN4-5 to lower part of NN11 Zone, to $3 \%$ in NN11 to NN16 Zone.

\subsection{Size Variation}

We measured the coccolith size of Reticulofenestra specimens in each samples to clarify the size distributions of them, throughout the sequence (Figure 4).

The increase trend of the maximum size is recognized in the following four intervals, NN2 to NN4-5 Zone, NN4-5 to NN8-10 Zone, NN11 to NN12 Zone, and NN13 to 15 Zone. As shown in Figure 4, the statistical modal size of them shows the repetition of apparent gradual increasing period and abrupt size decresing. The left column of Figure 4 shows that the majority of Reticulofenestra showed change in size in associated with change in modal size, suggesting the flora kept the statistical Gauss distribution in size throughout time. It is noteworthy that the change in the maximum size of

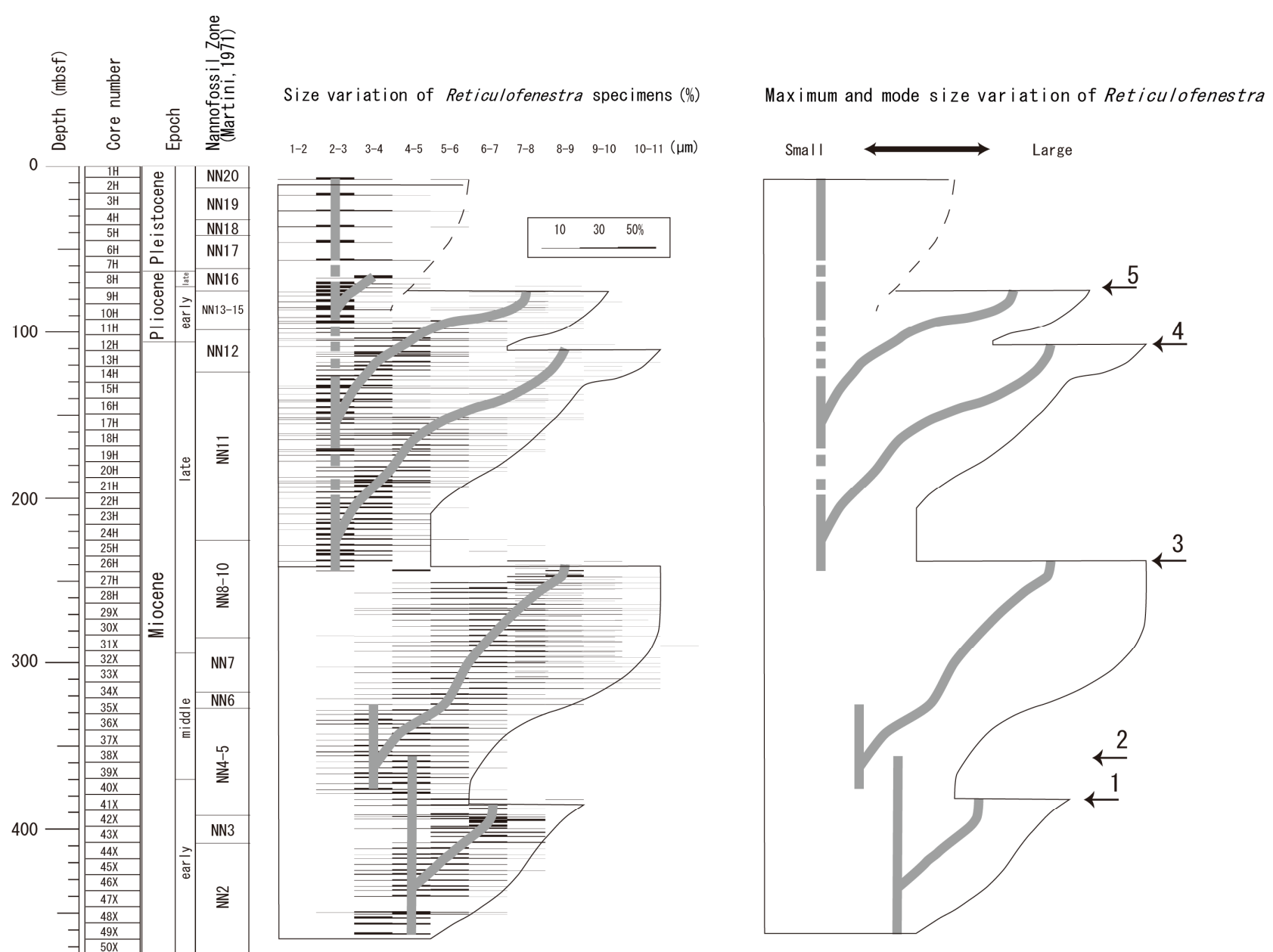

Figure 4. Comparison between distribution of size variation of Reticulofenestra specimens (\%) and the maximum and mode size of Reticulofenestra. 
Reticulofenestra is well recognized rather than the minimum size of them as shown in Figure 4. This looks as like that the mode of the Reticulofenestra size is characterized by positive correlation with maximum size. Not only does Figure 4 show the size change in the mode, but also the bimodal distributions are marked every interval before and after the termination of maximization (Figure 4). The bimodal patterns are composed of both unchanged small groups and maximized large groups. Although the smaller size mode is not distinct in the early to middle Miocene sequence, 2 - 3 micron Reticulofenestra specimens mark a clear mode in the interval of NN11 to NN20 Zone. However, these two small and large groups are not always concurrently present throughout the time. The small size mode is not detected in the intervals in NN2 to NN10 Zone of the early to middle Miocene, while the maximized phenomena have been unextinguished since the late NN16.

\section{Discussion}

\subsection{Background of Ecology and Paleoecology Nannoplankton}

The relation between the structure of the sea surface and the ecology of coccolithophorids have been clarified in previous studies [1,2,10]. Molfino and McIntyre [1] described that Florisphaera profunda lives in lower photic zone in recent ocean, so that its relative abundance decreases in upwelling environment, because of the upward moving the nutricline. Hagino et al. [2] studied the ecology of the coccolithophorids in the western equatorial Pacific Ocean and clarified that the lower photic zone species disappear in unstable surface conditions such as upwelling environment. Takahashi and Okada [3] reconstructed the paleoenvironment of the Quaternary southeastern Indian Ocean based on the abundance of $F$. profunda. Although the abundance of $F$. profunda is a good proxy for reconstruction of sea surface stability, the species does not occur in the Miocene sequence. Instead, Dis- coaster species is useful to similar purpose.

Discoaster species occur abundantly in the Paleogene to Neogene intervals and had been interpreted as a typical warm water species [11]. Recently, Aubry [12], Flores et al. [13], Stoll et al. [14] and Sato and Chiyonobu [15] summarized that the Discoaster species are a typical lower photic zone species same as F. profunda. Sato and Chiyonobu [15] studied the relationship between the size changes of coccolith and Discoaster abundance in the Paleogene to Neogene sequences, and described the changes of stability of the sea surface conditions briefly.

Coccolith size changes in the Neogene sequence were discussed by Young [16] and Kameo and Bralower [17] and indicated as a proxy of stratigraphic utility. Recently, the size changes and productivity of coccolith are dis- cussed as the characteristics of coccolith K-r selection $[15,18]$. It means that oligotrophic and eutrophic conditions are related to the development of both thermocline and nutricline, since they strongly influence to the productivity and size of coccolith.

\subsection{Paleoceanography of the Western Equatorial Pacific Ocean}

Our results indicate that lower photic zone species Discoaster decreased step by step (Figure 5). This means that thermo- and nutri-cline developed in NN2 to the upper part of NN4-5 Zone. However the thermo- and nutri-cline collapsed step by step from the upper part of NN4-5 zone to the NN10/NN11 boundary. The change in relative abundance is also closely related with the stepwise change in the modal size of Reticulofenestra (Figure 5). The termination 2 shown in Figure 5 is characterized by discontinuity in size changes, which is situated roughly in the same horizons of significant changes in Discoaster abundance. This spontaneous event can be explained by the stepwise collapse of the thermo- and nutri-cline collapsed step by step at NN4-5 Zone and NN10/NN11 boundary. As a result, the sea surface of the western equatorial Pacific Ocean changed from oligotrophic mode to eutrophic condition.

The maximum size of coccolith (Reticulifora) changed four times at the termination 1, 3, 4, and 5 (Figure 5). Differing from termination 2 , it is unlikely to be positively compared with the changes in Discoaster abundance. This will be interpreted that minor paleoceanographic changes occured across the termination 1, 4, and 5 , respectively.

\section{Conclusions}

We describe in detail the nannofossil biostratigraphy of the Hole $805 \mathrm{~B}$ is located in the western equatorial Pacific Ocean. The sequence is correlated to NN2 to NN20 Zones of early Miocene to Quaternary based on 13 nannofossil datums.

Collapse of the changes of Discoaster relative abundance and the coccolith size indicates that the thermoand nutri-cline progressed step by step at NN4-5 Zone and NN10/NN11 boundaries. As a result, sea surface of the western equatorial Pacific Ocean has been changed from oligotrophic to eutrophic conditions during the Miocene to Quaternary.

\section{Acknowledgements}

The authors are grateful to S. Chiyonobu, I. Kita, and N. Suzuki for critically the manuscript. Sample for this study were provided by the Oceanic Drilling Program Also thanks to JBIC (Japan Bank International Coope- 

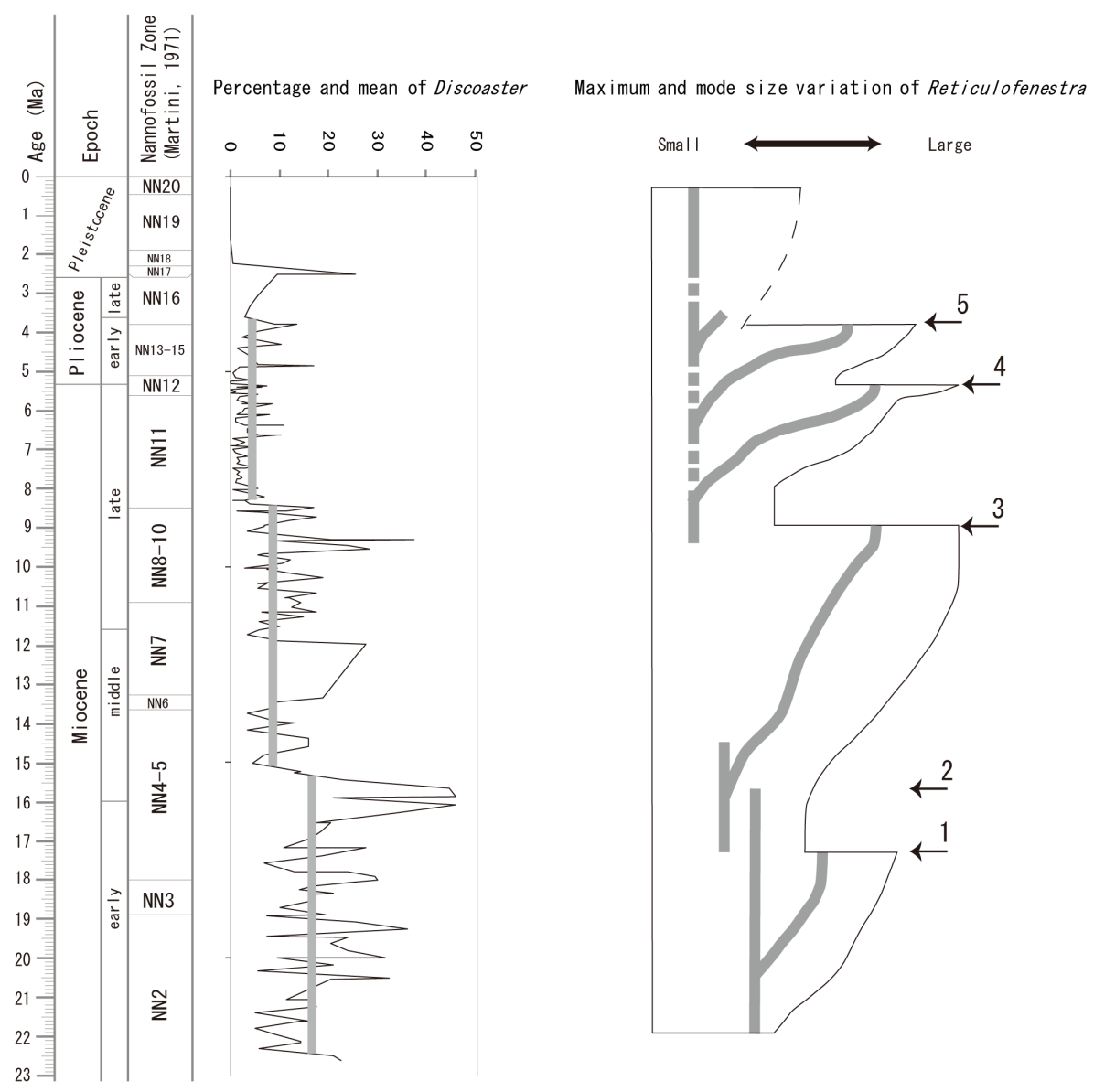

Figure 5. Simplified illustrations of percentage and mean of Discoaster, and also shown in left figure both maximum size and mode of Reticulofenestra.

ration) for supporting our research.

\section{REFERENCES}

[1] B. Molfino and A. McIntyre, "Precessional Forcing of Nutricline Dynamics in the Equatorial Atlantic," Science, Vol. 249, No. 4970, 1990, pp. 766-760. doi:10.1126/science. 249.4970 .766

[2] K. Hagino, H. Okada and H. Matsuoka, "Spatial Dynamics of Coccolithophore Assemblages in the Equatorial Western-Central Pacific Ocean," Marine Micropaleontology, Vol. 39, No. 1-4, 2000, pp. 53-72. doi:10.1016/S0377-8398(00)00014-1

[3] K. Takahashi and H. Okada, "The Paleoceanography for the Last 30.000 Years in the Southeastern Indian Ocean by Means of Calcareous Nannofossils," Marine Micropaleontology, Vol. 40, No. 1-2, 2000, pp. 83-103. doi:10.1016/S0377-8398(00)00033-5

[4] D. Bukry, "Discoaster Evolutionary Trends," Micropaleontology, Vol. 17, No. 1, 1971, pp. 43-52. doi: $10.2307 / 1485036$

[5] S. A. Nathan and R. M. Leckie, "Early History of the Western Pacific Warm Pool during the Middle to Late Miocene ( 13.2 - 5.8 Ma): Role of Sea-Level Change and
Implications for Equatorial Circulation," Palaeogeography, Palaeoclimatology, Palaeoecology, Vol. 274, 2009, pp. 140-159. doi:10.1016/j.palaeo.2009.01.007

[6] L. W. Kroenke, W. H. Berger, T. R. Janecek, et al., Proceedings of the Ocean Drilling Program, Initial Reports, Vol. 130, 1991, pp. 223-290.

[7] E. Martini, "Standard Tertiary and Quaternary Calcareous Nannoplankton Zoantion," In: A. Farinacci, Ed., 2nd Proceedings of Planktonic Conference, Roma, Vol. 2, 1971, pp. 739-785.

[8] B. Balestra, P. Ziveri, S. Monechi and S. Troelstra, "Late Quaternary Coccolithophorid Palaeoceanography from the SE Greenland Margin," 8th International Nannoplankton Association Conference, Bremen, 11-15 September 2000 .

[9] K. Baumann, J. R. Young, M. Cachão and P. Ziveri, "Biometric Study of Coccolithus Pelagicus and Its Palaeoenvironmental Utility," Journal of Nannoplankton Research, Vol. 22, No. 2, 2000, p. 82.

[10] H. Okada and S. Honjo, "The Distribution of Oceanic Coccolithophorids in the Pacific," Deep-Sea Research, Vol. 20, 1973, pp. 355-374.

[11] D. Bukry, "Low-Latitude Coccolith Biostratigraphic Zonation," Initial Reports of the Deep Sea Drilling Pro- 
ject, Vol. 15, 1973, pp. 685-703.

[12] M.-P. Aubry, "Late Paleogene Calcareous Nannoplankton Evolution: A Late of Climatic Deterioration," In: D. R. Prothero and W. A. Berggren, Eds., Eocene-Oligocene Climatic and Biotic Evolution, Princeton University Press, Princeton, 1992, pp. 272-309.

[13] J. A. Flores, F. J. Sierro, J. M. Filippelli, M. A. Barcena, M. Perez-Folgado, A. Vazquez and R. Utrilla, "Surface Water Dynamics and Phytoplankton Communities during Deposition of Cyclic Late Messinian Sapropel Sequences in the Western Mediterranean," Marine Micropaleontology, Vol. 56, No. 1-2, 2005, pp. 50-79. doi:10.1016/j.marmicro.2005.04.002

[14] H. M. Stoll, N. Shimizu, D. Archer and P. Ziveri, "Coccolithophore Productivity Response to Greenhouse Event of the Paleocene-Eocene Thermal Maximum," Earth and Planetary Sciense Letters, Vol. 258, No. 1-2, 2007, pp. 192-206. doi:10.1016/i.eps1.2007.03.037

[15] T. Sato and S. Chiyonobu, "Cenozoic Paleoceanography
Indicated by Size Change of Calcareous Nannofossil and Discoaster Abundance," Fossils, the Palaentological Society of Japan, Vol. 86, 2009, pp. 12-19.

[16] J. Young, "Size Variation of Neogene Reticulofenestra Coccoliths from Indian Ocean DSDP Cores," Journal of Micropalaeontology, Vol. 9, 1990, pp. 71-85. doi:10.1144/jm.9.1.71

[17] K. Kameo and T. J. Bralower, "Neogene Calcareous Nannofossil Biostratigraphy of Sites 998, 999, and 1000, Caribbean Sea," In: R. M. Leckie, H. Sigurdsson, G. D. Acton and G. Draper, Eds., Proceedings of ODP Scientific Results, College Station, Ocean Drilling Program, Vol. 165, 2000, pp. 3-15.

[18] P. R. Bown, J. A. Less and J. R. Young, "Calcareous Nannoplankton Evolution and Diversity Through Time," In: H. R. Thierstein and J. R. Young, Eds., Coccolithophores from Molecular Processes to Global Impact, Springer, Berlin, 2004, pp. 481-508. 